Original Research

\title{
Spirituality Level, Family Support, and Spiritual Self Care Behavior among Patient with Diabetic Ulcers
}

\author{
Ika Nur Pratiwi ${ }^{1 *}$, Kusnanto Kusnanto ${ }^{1}$, Malinda Kurnia Putri ${ }^{1}$ \\ ${ }^{1}$ Faculty of Nursing, Universitas Airlangga, Surabaya, Indonesia
}

\begin{tabular}{|c|c|}
\hline Article Info & Abstract \\
\hline $\begin{array}{l}\text { Article history: } \\
\text { Received: } \\
10 \text { May } 2020 \\
\text { Accepted: } \\
12 \text { July } 2020\end{array}$ & $\begin{array}{l}\text { Introduction: Patients with diabetic ulcers tend to experience problems in } \\
\text { implementing spirituality practices. Patients with diabetic ulcers also } \\
\text { experience weaknesses and impaired mobilization that have an impact on } \\
\text { family dependence and decreased self-efficacy. The purpose of this study } \\
\text { was to determine the relationship between spirituality level and family } \\
\text { support with spiritual self-care behavior in diabetic ulcer patients. }\end{array}$ \\
\hline $\begin{array}{l}\text { Keywords: } \\
\text { family support, } \\
\text { spiritual self-care, } \\
\text { spirituality level, } \\
\text { diabetic ulcer }\end{array}$ & $\begin{array}{l}\text { Methods: A descriptive correlation design with a cross-sectional approach. } \\
\text { In a total of } 92 \text { patients with diabetic ulcers in Sidoarjo General District } \\
\text { Hospital in June-July } 2019 \text { recruited. Independent variables were the level } \\
\text { of spirituality and family support. The dependent variable was spiritual } \\
\text { self-care behavior. Data obtained through the Daily Spiritual Experience } \\
\text { Scale (DSES) questionnaire, family support questionnaire, and Spiritual } \\
\text { Self Care Practice (SSCPS) questionnaire. Data were analyzed using the Chi- } \\
\text { square test of categorical variables with a } p \text {-value } \leq 0.05 \text { and logistic } \\
\text { regression for multivariate analysis. } \\
\text { Results: The study showed there was a significant relationship between } \\
\text { spirituality level ( } p=0,000 \text { ) and family support ( } p=0,001 \text { ) with spiritual } \\
\text { self-care behavior in diabetic ulcer patients. The result of regression } \\
\text { analysis showed the respondents with a high level of spirituality would } \\
\text { increase } 0.138 \text { times of the spiritual self-care behavior probability. } \\
\text { Conclusion: The level of spirituality and family support can promote } \\
\text { individual coping to be more positive which may accelerate the process of } \\
\text { receiving and healing wounds. }\end{array}$ \\
\hline
\end{tabular}

${ }^{*}$ Corresponding Author:

e-mail: ikanurpratiwi@fkp.unair.ac.id

This work is licensed under a Creative Commons Attribution 4.0 International License. 


\section{INTRODUCTION}

A diabetic ulcer is one of the severe chronic complications which is quite common in Diabetes Mellitus (DM) patients. Based on research data conducted by the International Diabetes Federation (IDF), the diabetic peripheral neuropathy is likely to occur as much as $16-66 \%$. The number of amputations in Diabetes Mellitus (DM) patients is $10-20$ times more frequent compared to nondiabetic people. It is estimated that the incidence of diabetic ulcers will continue to increase following the incidence of diabetes [1]. In Indonesia, the prevalence of diabetic ulcer patients is $15 \%$ of DM patients. People with a history of diabetic ulcers have the possibility of recurrence. For 5 years the likelihood for re-injury is $66 \%$ and amputation is $12 \%$ [2]. Based on preliminary studies, it was found that in 2016 the incidence of diabetic ulcers in Sidoarjo General District Hospital was 250 patients and in 2017, the number escalated up to 380 patients.

Patients with diabetic ulcers tend to experience problems in the implementation of spirituality practices. One effort to meet the spiritual needs of patients to performing spiritual practices known by term of spiritual self-care behavior [3]. Moreover, patients with diabetic ulcers have another tendency to experience problems such as physical weakness and decreased ability to mobilize which have an impact on decreased ability to perform daily activities, family dependency, lower self-efficacy, and low recovery expectancy $[3,4]$.

Based on the results of preliminary studies, it was found that some patients expressed a sense of dependency on people around them, experienced a decreased ability to perform daily activities, and a tendency to withdraw from social life. Some patients also stated the inability to practice prayer due to their wounds, physical weakness, lack of knowledge about how to purify, and misperception about impure wounds. Patients with diabetic ulcers tend to rely on the family for the fulfillment of daily needs [5]. One of the major family assistance was in meeting patient's spiritual needs [6].

Diabetes Mellitus is a chronic disease that occurs for a long time. The DM patients with complications have a susceptibility to stress. A body with psychologically depressed will have another susceptibility to experiencing other diseases because stress hormones will inhibit T-cells, macrophage activity, and reduce the number of lymphocytes. This condition, if left unchecked, will be resulting in another body immunity degradation following a disease vulnerability and slower the wound healing process [5]. Psychological factors such as depression not only affect the quality of life but also affect the ability to fight chronic disease progression [3, 7]. Psychological pressure on DM patients is influenced by the level of spirituality and religious adherence, the poor quality of the spiritual level will increase the risk for the patient to experience depression and resulting in a decrease in quality of life $[8,9]$.

Spirituality is an individual's belief in the purpose life, the meaning of the environment and fellow human beings, and the meaning of God $[3,10]$. Spirituality is proven to be one of the effective methods of coping strategies. When a patient has positive coping control, it 
will affect the ability to control pain as well increases the illness acceptance and improve the quality of life $[5,10,11]$.

Spiritual self-care is defined as spiritual activities perform by individuals to maintain and improve personal well-being when in health or sickness. Spiritual self-care is based on mind-body-spirit, moral, religious background, and experiences related to beliefs, feelings, and emotional connections. Spiritual self-care activities can include meditation, listening to the calming instrumental music, practicing yoga or tai chi, following religious activities, and praying. A person can improve spirituality and quality of life by participating in spiritual self-care activities, especially for patients with chronic illness. They are required to do any spiritual self-cares to not only improve quality of life but also restore their physical condition [3].

The relationship between the level of spirituality and family support with self-care spiritual behaviour can lead to an increase in the quality of life and self-acceptance of illness which will have implications for the physical and psychological health status as well as to increase wound healing. This study aimed to examine the relationship between the level of spirituality and family support with self-care spiritual behavior in diabetic ulcer patients.

\section{METHODS}

A descriptive correlation design with a crosssectional approach was used. In a total of 92 diabetic ulcer patients recruited based on Sidoarjo General District Hospital medical records between June-July 2019. Using a total sampling technique, respondents were invited for those who met the inclusion criteria: aged 26-65 years, patients living with family, and used the 3rd class of National Health Insurance (JKN) program by the Badan Penyelenggara Jaminan Sosial (BPJS) Kesehatan (Healthcare and Social Security Agency). The exclusion criteria in this study were DM patients with grade 0 diabetic ulcers according to the Meggitt Wagner classification [12].

The data collection process starts with research licensing as a preparation stage. The paper-based questionnaires were used to collect the participant information.. The study was conducted every two weeks to avoid the presence of the same respondents. It was also due to the prediction of the length of stay among each patient was 5-10 days. In the beginning, the researcher came to the concerned room that has been designated by the hospital and the data collection process was accompanied by the nurse on duty. Respondents who agree to participate in the study will be given an approval letter, have to sign the consent form, and asked to fill out the research questionnaires.

In this study respondents were required to fill out the demographic data questionnaires, Daily Spiritual Experience Scale (DSES) questionnaire, family support questionnaire, and Spiritual Self Care Practice (SSCPS) questionnaire. A self-generated demographic data questionnaire contained the respondent's identity including respondent's number, gender, age, education, occupation, marital status, living status with family, religion, length of time suffered by the $\mathrm{DM}$, and grade of diabetic ulcer.

The level of spirituality was measured using a DSES questionnaire to assess the level 
of personal spiritual experience in everyday life [13]. This questionnaire consists of 16 questions using a Likert scale. DSES-16 has internal consistency (Cronbach alpha score) on Chinese translation is 0.97, Germany translation is 0.92 , Khanna translation is 0.95 , and the Spanish translation score is 0.91 . The reliability test of DSES-16 Bahasa Indonesia translation was performed in 20 respondents, the result of Cronbach alpha scored 0.90 to 0.97 implies the reliable questionnaire.

Family support is measured using a family support questionnaire to assess family efforts to assist the needs of patients during illness [14]. The results of validity tests $(r=$ $0.4821)$ and reliability $(r=0.950)$ were obtained from previous studies using 20 respondents. This questionnaire consisted of 12 questions with 4 criteria including informational family support, instrumental family support, emotional family support, and appreciation. The answer options are based on a Likert scale of 0 (never), 1 (sometimes), 2 (often), and 3 (always).

The spiritual self-care behavior was measured using the SSCPS questionnaire to assess spiritual self-care practices in patients with chronic heart failure [15]. Previous researchers have tested the validity and reliability of the instrument. The results of validity and reliability test showed Cronbach alpha's value of 0.92 , the value of $r$ count $>r$ tableimplies this questionnaire is reliable for 20 respondents. This questionnaire consists of 36 questions with 4 domains including evaluating the implementation of personal spiritual practices, implementation of spiritual practices, implementation of physical-spiritual practices, and implementation of spiritual practices that relate to other people. The answer options are based on the Likert scale, 1 (never), 2 (rarely), 3 (often), 4 (very often), and 5 (always).

The data were analyzed using the Chisquare test to assess the frequency distribution of categorical variables with a pvalue $\leq 0.05$ and logistic regression for multivariate analysis. All statistical tests were carried out using SPSS version 21.

This research has obtained ethical approval from the Ethics Commission of Sidoarjo General District Hospital on May 27, 2019, with ethical number: $893.3 / 2171 / 438.6 .7 / 2019$ by emphasizing WHO seven ethical issues standards (2011) : 1) Social Value, 2) Scientific Value, 3) Equalization of burdens and benefits, 4) Risk, 5) Persuasion/Exploitation, 6) Confidentiality and Privacy, and 7) Approval before explanation which also referred to the 2016 CIOMS guidelines. Written informed consent was obtained from all patients prior to their inclusion in the study, and anonymity was ensured. Diabetic ulcer patients who have met the criteria are offered to become a study participant by explained the research objectives and the benefits. The confidentiality for data and identity information was ensured,,the respondent's name also modified in code. The participation of respondents in this study are voluntary and reserve the right to resign.

\section{RESULTS}

Based on the demographic data of the respondents in Table 1 the majority of respondents were male with a total of 52 respondents (56.7\%). Most of the 
respondents were in the early elderly age between 46-55 years ( $\mathrm{N}=61,70 \%)$. To the occupational status, most respondents were working as housewives $(\mathrm{N}=31,33.3 \%)$. The majority of the respondents accomplished secondary education (SMA) $(\mathrm{N}=60,76.7 \%)$. All respondents are Muslims. Based on the grade of diabetic ulcer, most of respondents were diagnosed as grade $2(\mathrm{~N}=44,53.3 \%)$ with ulcers reaching the tendon. Based on the findings it can be seen that the data distribution is disproportionate (Table 1).

Based on the Chi-square test results in Table 2 there was a significant relationship between spirituality level and the spiritual self-care behavior with a Sig. 0.000 ( $p$-value $<0.05)$. On the level of spirituality, the majority of respondents showed a low level of spirituality and spiritual self-care behavior (N $=32,78 \%$ ). Meanwhile to the family support, spirituality self-care behavior showed a Sig. 0.001 ( $p$-value $<0.05$ ), it can be concluded that there was a significant relationship between family support and spiritual self-care behavior. The majority of respondents showed a high spiritual self-care behavior and family support $(\mathrm{N}=34,66.7 \%)$.

Table 3 shows the results of multivariate analysis, the highest level of spirituality affected spiritual self-care behavior ( $p$-value $<0.05)$. Another interpretation of the results,a high level of spirituality would increase 0.138 times the spiritual self-care behavior probability.

\section{Table 1}

Demographic data of respondents

\begin{tabular}{|c|c|c|c|c|}
\hline \multirow{2}{*}{ No } & \multirow{2}{*}{ Characteristics } & \multirow{2}{*}{ Category } & \multicolumn{2}{|c|}{$\mathbf{N}$} \\
\hline & & & f & $\%$ \\
\hline \multirow[t]{2}{*}{1} & \multirow[t]{2}{*}{ Gender } & Male & 52 & 56,7 \\
\hline & & Female & 40 & 43,3 \\
\hline \multirow[t]{2}{*}{2} & \multirow[t]{2}{*}{ Age } & Early elderly (46-55 years) & 61 & 70,0 \\
\hline & & Late elderly (56-65 years) & 31 & 30,0 \\
\hline \multirow[t]{4}{*}{3} & \multirow[t]{4}{*}{ Job } & Private & 24 & 20,0 \\
\hline & & Entrepreneur & 29 & 36,7 \\
\hline & & Housewife & 31 & 33,3 \\
\hline & & Does not work & 8 & 10,0 \\
\hline \multirow[t]{2}{*}{4} & \multirow[t]{2}{*}{ Education } & Primary education & 32 & 23,3 \\
\hline & & Secondary education & 60 & 76,7 \\
\hline \multirow[t]{4}{*}{5} & \multirow[t]{4}{*}{ Marital status } & Single & 1 & 1,1 \\
\hline & & Married & 83 & 90,0 \\
\hline & & Widower & 4 & 6,7 \\
\hline & & Widow & 4 & 3,3 \\
\hline 6 & Religion & Islam & 92 & 100 \\
\hline \multirow[t]{2}{*}{7} & \multirow[t]{2}{*}{ Status of living with family } & Nuclear family & 29 & 30,0 \\
\hline & & Extended family & 63 & 70,0 \\
\hline \multirow[t]{2}{*}{8} & \multirow{2}{*}{$\begin{array}{l}\text { length of time diagnosed } \\
\text { with DM }\end{array}$} & $<5$ year & 36 & 26,7 \\
\hline & & $>5$ year & 56 & 73,3 \\
\hline \multirow[t]{4}{*}{9} & \multirow[t]{4}{*}{ Grade ulcers } & Grade 1 & 26 & 20,0 \\
\hline & & Grade 2 & 44 & 53,3 \\
\hline & & Grade 3 & 22 & 26,7 \\
\hline & & Total & 92 & 100 \\
\hline
\end{tabular}


Table 2

Relationship between spirituality level and family support with spiritual self-care behaviour

\begin{tabular}{|c|c|c|c|c|c|}
\hline \multirow{3}{*}{ Variable } & \multicolumn{4}{|c|}{ Spiritual self-care behaviour } & \multirow[t]{3}{*}{ p-value* } \\
\hline & \multicolumn{2}{|c|}{ Low } & \multicolumn{2}{|c|}{ High } & \\
\hline & f & $\%$ & f & $\%$ & \\
\hline Spirituality level & & & & & 0,000 \\
\hline Low & 32 & 78.0 & 14 & 22.0 & \\
\hline High & 9 & 27.5 & 37 & 72.5 & \\
\hline Family support & & & & & 0,001 \\
\hline Low & 28 & 68.3 & 17 & 31.7 & \\
\hline High & 13 & 33.3 & 34 & 66.7 & \\
\hline
\end{tabular}

${ }^{*}$ Chi-squared test $(\mathrm{p} \leq 0.05)$

$\%$ within spiritual self-care behavior

Table 3

Multivariate analysis of independent variables with spiritual self-care behavior

\begin{tabular}{lccc}
\hline \multicolumn{1}{c}{ Variable } & $\boldsymbol{p}$ & OR adjusted & 95\% CI adjusted \\
\hline Step 1 & & & \\
\hline Spirituality level & 0.000 & 0.138 & $0.051-0.373$ \\
\hline Family support & 0.058 & 0.385 & $0.143-1.032$ \\
\hline
\end{tabular}

\section{DISCUSSION}

Diabetic ulcer patients tend to experience various problems related to the reduced ability to perform daily activities, physical changes, and socioeconomic relationships. Patients who suffered from chronic diseases for a long time are required to be able to adapt and manage their illnesses, such as overcoming pain, discomfort, psychological related problems, physical, social, and lifestyle changes [16].

Previous research explained that the level of spirituality creates a specific practice of spiritual self-care, such as personal spiritual practices (resting, feeling peaceful, complying with health regulations), general spiritual practices (praying, following religious events), physical spiritual practices (doing yoga/taichi, walking, doing physical activities), and spiritual practices related to other people. Spiritual self-care is an effort to developing and prospering the health also medicate the diseases based on spiritual practices [15]. These findings were in line with research conducted by White \& Schim (2013) about the relationship between the level of spirituality and spiritual self-care behavior in diabetic ulcer patients [15].

Concerning the results on the level of sprituality and spiritual self-care behavior, most of the respondents in this study had a low level of spirituality and spiritual self-care behavior $(\mathrm{N}=32,78 \%)$. This result was in line with the research conducted by Salome et al. (2017) which states that diabetic ulcer patients aged less than 60 years have a low level of spirituality [4]. This difference was influenced by several factors such as the 
period of illness, patient's health status, and life experiences related to spirituality [17].

Patients in this study mostly suffered from the disease for more than 5 years and developed a grade 2 ulcer (the ulcer wound reaching the tendon). The length of time diseased with illness creates adaptation and affected their life experience related to spirituality. Most of the patients have a sense of sincerity and resignation to the condition. The patients are required to adapt to their wound condition and seeks knowledge on how to perform the prayer when they have a wound. Most of the respondents were sitting while praying, some others claimed to pray by standing when the body condition is stable, and the wound is dry.

Another finding In this study showed that belief in spirituality does not affect the implementation of the practice of religiosity. The practice of religiosity is referred to the prayer and active participation in attending religious services at church. The research conducted in Romanian and Bulgarian society showed that women have a higher level of spirituality than men, but the high level of spirituality does not affect the activity in following spiritual practices such as coming to church. This is influenced by physical limitations that also influence a person in practicing spirituality [18]. In line with the results of this study, there were respondents with high levels of spirituality but had a low spiritual self-care behaviour $(\mathrm{N}=9.27 .5 \%)$, it is expected due to physical limitations. In patients with diabetic ulcers, complications will cause pain, weakness in mobilizing, and foul odors along with the pus discharges in the wound. In line with research conducted by
Coleman et al., (2015) a personal physical limitations influence the implementation of spiritual practices [18].

Having diabetic ulcers will decrease the patient's ability to in performing daily activities. Moreover, pain and immobilization will significantly impact the patient's quality of life. Any impact that arises makes patients with diabetic ulcers tend to depend on family or closest friends in performing daily activities $[19,20]$.

Another research study conducted by Riskiana (2014) suggested that individuals with social support such as family and neighborhood should have a better strategy and problem-solving abilities. Other research also stated family has a big role for DM patients in providing support related to health and spiritual fulfillment [6].

In line with the above research, the finding in this study showed a relationship between family support and self-care spiritual behavior in diabetic ulcer patients. The higher family support will increase the spiritual behavior of self-care patients with diabetic ulcers. Vice versa, when the family support is low, the practice of spiritual self-care will decrease.

Contrarily unexpected finding occurs, there are respondents with low family support but have a high self-care spiritual behavior $(\mathrm{N}=17,31.7 \%)$. Patients who have good spiritual practices apart from low family support indicate a succesful coping mechanisms. The practice of spirituality is proven to be able to help someone with a chronic illness to accept and adapt to physical, psychological, and social changes [15]. 
In this study, there were also respondents with high family support but had low self-care spiritual behavior $(\mathrm{N}=13$, $33.3 \%)$. Patients with good family support but low self-care spiritual behavior can be influenced due to many factors such as age and education. In elder patients, the inability to perform activities will get worse [19]. Good family support not accompanied by the patient's ability to carry out activities resulting in non-effectivespiritual practices. The level of education also influences the ability of families to provide support and the ability of patients to receive support [21].

Diabetic ulcer patients who have a high level of spirituality will have a high level of self-care spiritual behavior, the high level of spirituality support the effectiveness of the treatments. In this study, we also found the respondentwith a high level of spirituality would increase 0.138 times of their spiritual self-care behavior. Engaging in spiritual selfcare is strongly affected by the foundational disposition of spirituality. Spiritual self-care may be done by the person to feel a connection with a higher power. Spiritual selfcare may also be done to help the person feel connected to others, individuals may pursue other spiritual self-care practices that enhance their sense of well-being [17].

\section{CONCLUSION}

In this study, it was found that diabetic ulcer patients with an adequate level of spirituality and family support also had sufficient spiritual self-care behavior as well. Therefore, it is important to provide nursing care efforts to increase and optimize the level of spirituality and family support to achieve the optimal patient's spiritual self-care behavior . A good spiritual self-care behaviour will improve the quality of life and acceptance of the wounds as well as to accelerate the process of healing.

\section{REFERENCES}

[1] International Diabetes Federation, "IDF Diabetes Atlas Eighth Edition 2017," Brussels, 2017.

[2] S. Indrayana, S. E. Guo, C. L. Lin, and S. Y. Fang, "Illness Perception as a Predictor of Foot Care Behavior Among People with Type 2 Diabetes Mellitus in Indonesia," J. Transcult. Nurs., vol. 30, no. 1, pp. 17-25, 2019.

[3] M. L. White, "Spirituality Self-Care Practices as a Mediator between Quality of Life and Depression," Religions, vol. 7, no. 54, doi:10.3390/rel7050054, 2016.

[4] G. M. Salomé, S. A. de Almeida, B. Mendes, M. R. F. de Carvalho, J. C. Bueno, and M. R. Massahud Jr, and L. M. Ferreira, "Association of Sociodemographic Factors with Spirituality and Hope in Patients with Diabetic Foot Ulcers," Adv. Skin Wound Care, vol. 30, no. 1, pp. 3439 ,

doi:

10.1097/01.ASW.0000508446.58173.2 9, 2017.

[5] T. Suciani and T. Nuraini, "Kemampuan Spiritualitas dan Tingkat Stres Pasien Diabetes Mellitus di Rumah Perawatan: Studi Pendahuluan," J. Keperawatan Indones., vol. 20, no. 2, pp. 102-109, 2017.

[6] A. K. Wardani and M. A. Isfandiari, "Hubungan dukungan keluarga dan pengendalian kadar gula darah dengan 
gejala komplikasi mikrovaskuler," J. Berk. Epidemiol., vol. 2, no. 1, pp. 1-12., 2014.

[7] J. Chen, Y. Lin, J. Yan, Y. Wu, and R. Hu, "The effects of spiritual care on quality of life and spiritual well-being among patients with terminal illness: A systematic review," Palliat. Med., vol. 32, no. 7 , pp. 1167-1179, doi: 10.1177/0269216318772267, 2018.

[8] I. Ardian, "Spiritual and religion concept in nursing for diabetic melitus patients," Nurscope: J. Keperawatan dan Pemikir. Ilmiah, vol. 2, no. 2, pp. 40-48, 2016.

[9] S. A. Choi and J. F. Hastings, "Religion, spirituality, coping, and resilience among African Americans with diabetes," J Reli. Spirit. Soc Work ., vol. 38, no. 1, pp. 93114 , doi: 10.1080/15426432.2018.1524735, 2020.

[10] G. M. Salomé, V. R. Pereira, and L. M. Ferreira, "Spirituality and subjective wellbeing in patients with lower-limb ulceration," J. Wound Care, vol. 22, no. 5, pp. 234-6, doi: 10.12968/jowc.2013.22.5.230, 2013.

[11] S. Fallahi, A. S. Farahani, M. Rassouli, and R. Sefidkar, "The Effect of Spiritual Care on Self Confidence of Adolescents with Type 1 Diabetes," Iran. J. Endocrinol. Metab., vol. 20, no. 3, pp. 127-134, 2018.

[12] M. Mehraj and I. Shah, "A review of Wagner classification and current concepts in management of diabetic foot," Int. J. Orthop. Sci., vol. 4, no. 1, pp. 933-935, 2018.

[13] L. G. Underwood, "The Daily Spiritual Experience Scale: Overview and Results,"
Relig., vol. 2, no. 1, pp. 29-50; doi: 10.3390/rel2010029, 2011.

[14] M. N. Kurniawan, "Hubungan antara Dukungan Keluarga dengan Tingkat Kepatuhan Klien Tuberkulosis Paru dalam Menjalani Pengobatan di Puskesmas Pegirian Surabaya," Thesis, Univ. Airlangga, 2016.

[15] M. L. White and S. M. Schim, "Development of a Spiritual Self-Care Practice Scale," J. Nurs. Meas., vol. 21, no. 3, pp. 450-462, doi: 10.1891/10613749.21.3.450, 2013.

[16] K. White, M. S. M. Issac, C. Kamoun, J. Leygues, and S. Cohn, "The Thrive model: A framework and review of internal and external predictors of coping with chronic illness.," Heal. Psychol. Open, vol. 5, no. 2, pp. 1-14, doi: 10.1177/2055102918793552, 2018.

[17] M. L. White, R. Peters, and S. M. Schim, "Spirituality and Spiritual Self-Care: Expanding Self-Care Deficit Nursing Theory," Nurs. Sci. Quarterly, vol. 24, no. 1 pp. 48-56. doi: 10.1177/0894318410389059, 2011.

[18] P. G. Coleman, R. O. Carare, I. Petrov, E. Forbes, J. H. Spreadbury, A. Yap, and T. Kendrick, "Spiritual belief, social support, physical functioning and depression among older people in Bulgaria and Romania," Aging Ment. Heal., vol. 15, no. 3, pp. 327-333, doi: 10.1080/13607863.2010.519320, 2011.

[19] G. M. Salome, D. M. D. S. Pellegrino, L. Blanes, and L. M. Ferreira, "Self-esteem in patients with diabetes mellitus and foot ulcers," J. Tissue Viability, vol. 20, no. 3, pp. 100-106, doi: 
10.1016/j.jtv.2010.12.004, 2011.

[20] P. C. Lundberg and S. Thrakul, "Religion and self-management of Thai Buddhist and Muslim women with type 2 diabetes," J. Clin. Nurs., vol. 22., no. 13-14, pp.

1907-1916, doi: 10.1111/jocn.12130, 2013.

[21] Y. Y. Usta, Y. Dikmen, S. Yorgun, and I. Berdo, "Predictors of foot care behaviours in patients with diabetes in Turkey," PeerJ, vol. 7, pp. 1-12, doi: 10.7717/peerj.6416, 2019. 